\title{
Method of determining the efficiency of price and non-price competition in service sector
}

\author{
Nadezhda Savel'eva ${ }^{1, *}$, Lyudmila Prokopenko ${ }^{1}$, Nadezhda Zueva ${ }^{1}$, Andrey Kuklin ${ }^{1}$, and \\ Ilia Yanov ${ }^{2}$ \\ ${ }^{1}$ Vyatka State University, Moskovskaya str., 36, Kirov, 610000, Russia \\ ${ }^{2}$ Moscow State University of Civil Engineering, Yaroslavskoe shosse, 26, Moscow, 129337, Russia
}

\begin{abstract}
With the end of 2014, the domestic banking system has serious difficulties with the availability of capital for lending and investment programs. Problems based on international political divisions, and their resolution lies in the distant future. in these circumstances, the government is concerned about the development of the Russian banking system in terms of ensuring their competitiveness in the international arena. foreign capital has always been a cheap resource for the domestic banking system, the problem area remains its state at the time of lifting of sanctions. Nowadays banks are forced to use different competition methods in target to adapt to environmental changes and ensure competitive success. So the development of methods for price and non-price competition has economic importance. Analysis of qualitative methodological foundations in banks service revealed strong background. Based on neoteric qualitative evaluation methodology, authors developed method for price and non-price competitiveness. It defines variables of price and non-price competitiveness, to set the value factors, to identify the closest competitors, and to set the position of a particular bank among other participants. It also helps to shape competitors dossier based on the evaluated score.
\end{abstract}

\section{Introduction}

It is very important in modern environment to identify the most valuable in the theory and practice of price and non-price competition, and on this basis, propose a mechanism for the selection of such methods, which on the one hand match characteristics of a particular business, on the other hand respond current market situation and trends. Increased banking competition and growing clients' demand to banking services leads to the fact that banks are forced to use methods and tools of competition to adapt to environmental changes and ensure competitive success. In order to determine the competitive position of a bank it is necessary to assess own effectiveness in banking market. This assessment is one of the most difficult tasks in management system. The reason is difficulty to track which

\footnotetext{
*Corresponding author:lutoshkinank@inbox.ru
} 
processes influence the economic result of organization's performance. This article will contribute to science the way to solve this problem.

The proposed method helps:

- to identify the main variables that determine price and non-price competition effect in banking market;

- to set the value (weighting factors), calculated according to specifics of target market;

- to determine the main approaches for management system of price and non-price competition in target market;

- to identify the closest competitors and to establish the relative position of bank among other market participants in terms of perception of price and non-price competition factors;

- to use received information for competitors dossier.

This method greatly facilitates bank managers' work, accelerates decision-making process, reduces the risk by obtaining objective information on market of individuals and entities.

\section{Materials and Methods}

Banking service is intangible: it cannot be felt or saw unless client receives it. The reason based on non-physical nature of service. In this regard, consumers are demonstrating increased attention to visible elements of service: banking equipment, appearance of staff, brand and all that can give indirect information about the nature and quality of services provided by a bank. In order to facilitate the perception of services to customers, a bank may try to establish a psychological association of banking services to any tangible and easier to realize object or to focus on the aspect of its communication with clients, to create the appearance of bank as a "good assistant", "adviser". A positive result for banking service promotion can also bring emphasis on benefits to consumers.

The purpose of this study is to form the scientific ground for development of qualitative methods in price and non-price competitiveness assessment according to specifics of banking market development and to increasing effectiveness of marketing activities. Research objects are economic relations in banking sector related to the methods of price and non-price competition [1-26].

The methodological basis of the study is dialectical method of cognition. The paper used research methods such as polling, monitoring, modeling, research and generalization. The theoretical basis consist of the works of classics of economic science, the works of modern economists related to the issues of competition and competitiveness of services, management, marketing, banking.

\section{Results}

The aim of the study is to develop a method for determining the efficiency of price and non-price competition in banking market on the basis of qualitative estimates (Table 1). In order to determine its competitive position, bank needs to assess the effectiveness of its activities in in market (Contemporary science: theoretical and practical review, 2015).

Table 1. Method for determination of effectiveness in implementation of events in banking market based on quality assessment.

\begin{tabular}{|c|c|c|}
\hline Stages & Description & Model, tools \\
\hline 1 & $\begin{array}{c}\text { Identification of main parameters that } \\
\text { determine price and non-price competition }\end{array}$ & $\begin{array}{c}\text { Price competition: } \mathrm{X}_{1}-\mathrm{X}_{16} \\
\text { Non-price competition: } \mathrm{X}_{1}-\mathrm{X}_{23}\end{array}$ \\
\hline
\end{tabular}




\begin{tabular}{|c|c|c|}
\hline & in banking market & \\
\hline 2 & $\begin{array}{l}\text { Scoring of basic parameters of price and } \\
\text { non-price competition }\end{array}$ & The tool of research - questionnaire \\
\hline 3 & $\begin{array}{l}\text { Determination of factor values loadings } \\
\text { based on factor analysis procedure }\end{array}$ & $\begin{array}{c}\text { Factor model: } \\
X_{i}=A_{i l} F_{1}+A_{i 2} F_{2}+\ldots A_{i m} F_{m}+V_{i} U_{i}\end{array}$ \\
\hline 4 & Determination of optimal number of factors & $\begin{array}{c}\text { Based on plotting eigenvalues of } \\
\text { number of factors }\end{array}$ \\
\hline 5 & $\begin{array}{l}\text { Defining parameters of price and non-price } \\
\text { competition that most correlated with main } \\
\text { factors }\end{array}$ & $\begin{array}{l}\text { Determined on the basis of factor } \\
\text { loadings (linear correlation between } \\
\text { variables and factors) }\end{array}$ \\
\hline 6 & Calculationof factor values & $\begin{array}{c}F_{i-\text { individuals }}=W_{i l} X_{1}+W_{i 2} X_{2}+\ldots+W_{i k} X_{k} \\
F_{i-\text { entities }}=W_{i 1} X_{1}+W_{i 2} X_{2}+\ldots+W_{i k} X_{k}\end{array}$ \\
\hline 7 & $\begin{array}{l}\text { Calculation of total index value of factors } \\
\text { for different periods }\end{array}$ & $F_{\text {total } t}=\Sigma F_{i \text {-individuals }}+\Sigma F_{\text {i-entities }}$ \\
\hline 8 & $\begin{array}{l}\text { Calculation of augmentation in } \\
\text { effectiveness score }\end{array}$ & $\begin{array}{c}\exists_{f}=F_{\text {total }}-F_{\text {total } t-1}=\left(\Sigma F_{\text {i-individuals }}+\Sigma F_{i}\right. \\
\text { entities })_{t}-\left(\Sigma F_{\text {i-individuals }}+\Sigma F_{\text {i-entities }}\right)_{t-1}\end{array}$ \\
\hline 9 & Graphical presentation of the results & $\begin{array}{l}\text { On the basis of multidimensional } \\
\text { scaling procedure in SPSS or procedure } \\
\text { of factor analysis in Minitab }\end{array}$ \\
\hline 10 & Interpretation of the results & $\begin{array}{l}\text { Conclusions and proposals for } \\
\text { improvements of management activities } \\
\text { in price and non-price competition }\end{array}$ \\
\hline
\end{tabular}

The main stages of method for assessing the effectiveness of proposed measures implementation:

Stage 1 - On the basis of existing methods and management tools of price and non-price competition in banking market determined the main parameters that affect price and nonprice competition in the banking market (Table 2) (Savel'eva, N.K., 2016).

Table 2. The main parameters that affect price and non-price competition in the banking market.

\begin{tabular}{|c|c|c|c|}
\hline \# & $\begin{array}{l}\text { The main parameters of } \\
\text { price competition }\end{array}$ & \# & $\begin{array}{l}\text { The main parameters of } \\
\text { non-price competition }\end{array}$ \\
\hline 1 & Loan rate & 1 & Quality of service \\
\hline 2 & $\begin{array}{l}\text { Various fees and bank } \\
\text { commissions }\end{array}$ & 2 & Information about services \\
\hline 3 & $\begin{array}{l}\text { Discounts and bonuses for credit } \\
\text { history }\end{array}$ & 3 & The boundaries of the product (range) \\
\hline 4 & $\begin{array}{l}\text { Discounts and bonuses for loyal } \\
\text { customers }\end{array}$ & 4 & $\begin{array}{l}\text { The ability to use service free of charge or in } \\
\text { preferential terms }\end{array}$ \\
\hline 5 & Annuity payment system & 5 & Location of bank \\
\hline \multirow[t]{2}{*}{6} & \multirow{2}{*}{$\begin{array}{l}\text { Differentiated payment system } \\
\text { (monthly payments are reducing) }\end{array}$} & 6 & Additional offices \\
\hline & & 7 & Work schedule and modes \\
\hline \multirow[t]{2}{*}{7} & \multirow{2}{*}{$\begin{array}{l}\text { The amount or per cent of } \\
\text { overpayment }\end{array}$} & 8 & Remote Banking \\
\hline & & 9 & Availability of ATMs, terminals \\
\hline
\end{tabular}




\begin{tabular}{|l|l|l|l|}
\hline 8 & Fees for compulsory insurance of & 10 & Possibility of payments by credit card \\
\cline { 3 - 4 } & & 11 & Advertising support \\
\hline 9 & Penalties for late payment & 12 & Direct marketing \\
\hline 10 & $\begin{array}{l}\text { Reduced rates by means of } \\
\text { refinancing or lending }\end{array}$ & 13 & Brand name \\
\cline { 3 - 4 } & 14 & Bank image \\
\hline 11 & Fees for cash service & 15 & Trustiness to bank \\
\cline { 3 - 4 } & & 16 & $\begin{array}{l}\text { Conducting raffles and lotteries among } \\
\text { customers }\end{array}$ \\
\hline 12 & Deposit rate & 17 & Bank's exterior \\
\hline 13 & $\begin{array}{l}\text { Credit and debit transactions in } \\
\text { deposit account }\end{array}$ & 18 & Bank's interior \\
\cline { 3 - 4 } & & 19 & Information design of the building \\
\hline 14 & $\begin{array}{l}\text { Interest Period and terms of } \\
\text { capitalization }\end{array}$ & 20 & Graphic symbol (logo) \\
\cline { 3 - 4 } & Payment of interim interest & 21 & Staff qualification \\
\hline 15 & $\begin{array}{l}\text { The rate for early withdrawal of } \\
\text { funds from deposit }\end{array}$ & 23 & Speed of service \\
\cline { 3 - 4 } & & 24 & Corporate style \\
\hline
\end{tabular}

Stage 2 - Scoring of basic parameters which determine price and non-price competition in banking market. Sampling evaluates the basic parameters for each bank.

Stage 3 - Determination of factor loading values on the parameters of price and nonprice competition at whole market of banking services based on factor analysis procedure. From a mathematical point of view, factor analysis is similar to the multiple regression analysis, in the sense that every variable is expressed as a linear combination of latent factors. If the variables are normalized, the factor model can be represented as follows:

$$
X_{i}=A_{i 1} F_{1}+A_{i 2} F_{2}+\ldots A_{i m} F_{m}+V_{i} U_{i}
$$

Where: $X_{i}-i^{\text {th }}$ normalized variable; $A_{i}$ - normalized multiple regression coefficient of $i^{\text {th }}$ variable corresponding to common factor $j ; F_{i}$ - commonfactor; $V_{i}$ - normalized regression coefficient of $i^{\text {th }}$ variable corresponding to factor $i ; U_{i}$ - factor for $i$-variable; $m$ - total quantity of factors.

The analysis is performed on the set of individuals and entities.

Stage 4 - Determination of the optimal number of factors to be included in the valuation model is based on scree plot (Figure 1). 


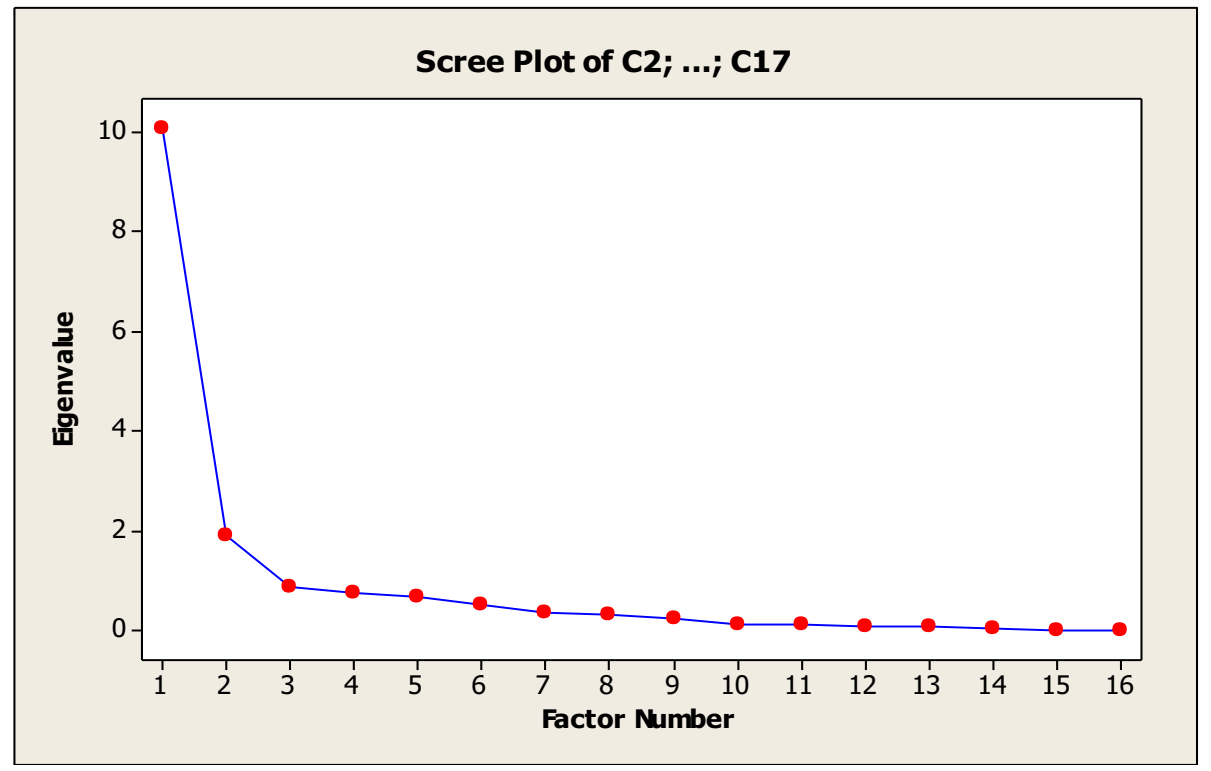

Fig. 1. Scree plot for determination of the optimal number of factors.

Stage 5 - Defining the parameters of price and non-price competition, which are the most correlated with the basic factors. It should be determined on the basis of factor loadings (linear correlation between variables and factors): the closer the loading value to 1 , the closer the relationship between factor and variable. The importance of the selection of variables has a parameter of entity. Community is the proportion of single variable variance, which is shared with other variables. For the accuracy and reliability of the results it is recommended to use for interpretation common variables with value over $60 \%$.

Stage 6 - After defining the variables with the highest factor loadings one can calculate the value of each factor. The factor is a linear combination of the original variables. The value for the $i^{\text {th }}$ factor can be calculated by the formula:

$$
F_{i}=W_{i 1} X_{1}+W_{i 2} X_{2}+\ldots+W_{i k} X_{k},
$$

Where: $F_{l}$ - score of $i^{\text {th }}$ factor; $W_{i}$-weight coefficient or coefficient values; $X_{i}-i^{\text {th }}$ normalized variable; $k$ - quantity of variables.

For market of banking services we determined values of factors for individuals and entities:

1. Values of the factors for market of individuals in parameters of non-price competition:

$$
F_{\text {i-individuals }}=W_{i 1} X_{1}+W_{i 2} X_{2}+\ldots+W_{i k} X_{k}
$$

Similarly should be determined coefficients for $F_{i}$ models for price competition in market of individuals and entities.

2. Values of the factors for market of individuals in parameters of price competition:

$$
F_{\text {i-individuals }}=W_{i 1} X_{1}+W_{i 2} X_{2}+\ldots+W_{i k} X_{k}
$$

3. Values of the factors for market of entities in parameters of non-price competition:

$$
F_{\text {i-entities }}=W_{i 1} X_{1}+W_{i 2} X_{2}+\ldots+W_{i k} X_{k}
$$


4. Values of the factors for market of entities in parameters of price competition:

$$
F_{i-e n t i t i e s}=W_{i 1} X_{1}+W_{i 2} X_{2}+\ldots+W_{i k} X_{k}
$$

Stage 7 - Calculation of total index value of factors for different periods:

$$
F_{\text {total }}=\Sigma F_{\text {i-individuals }}+\Sigma F_{\text {i-entities }}
$$

For calculation of this index need to calculate F-factor values for the current period and the previous period. The initial data is a numerical score of parameters included in the model.

Stage 8 - Augmentation in effectiveness score is the difference between value of factors in current period and in previous period:

$$
\ni_{f}=F_{\text {total } t}-F_{\text {total } t-1}=\left(\sum F_{\text {i-individuals }}+\Sigma F_{i \text {-entities }}\right)_{t}-\left(\Sigma F_{i \text {-individuals }}+\Sigma F_{i-}\right.
$$

Stage 9 - Graphical presentation of the research result in management efficiency of price and non-price competition in banking market. The score plot of perception had been constructed using multidimensional scaling procedure in SPSS and using factor analysis procedures in Minitab (Figure 2).

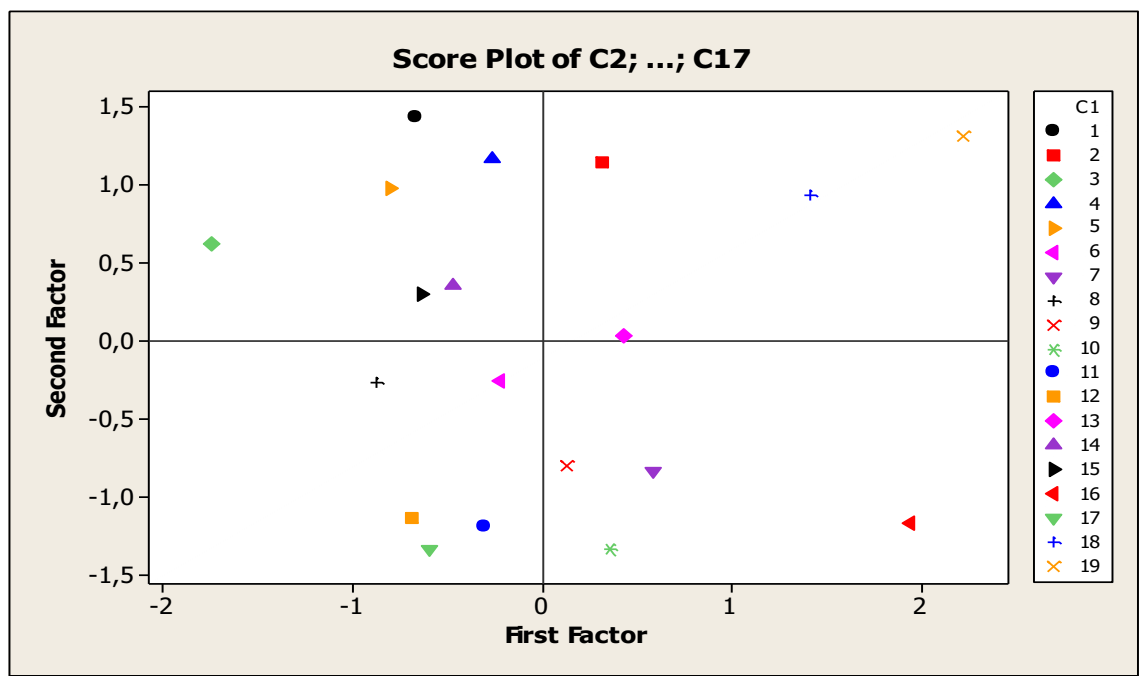

Fig. 2. Score plot of perception of factors in price and non-price competition by individuals and entities.

Thus, the proposed method helps:

- to identify the main variables that determine price and non-price competition effect in banking market;

- to set the value (weighting factors), calculated according to specifics of target market;

- to determine the main approaches for management system of price and non-price competition in target market;

- to identify the closest competitors and to establish the relative position of bank among other market participants in terms of perception of price and non-price competition factors;

- to use received information for competitors dossier. 
Competition has a positive impact on banking services market. In a competitive environment has formed an adequate offer: perfect product for a consumer. From the bank's perspective, the competition helps to assess realistically own capabilities. After testing the proposed method it is advisable to compare it with the known methods of evaluating the effectiveness of banks' activities (Savel'eva N., 2014).

The current qualitative methods of evaluating the effectiveness of the banks' activities are: method for assessment of qualitative parameters system by T.A. Ponomareva and, M.S. Supryagina; method for assessment of services from marketing point by N.N. Pavlova; model of banks' interaction with customers by V.S. Vikulov; method of expert assessment of commercial bank's stability by A.G. Zahar'yan; method by rating agency "Expert RA"; method by V.S. Kormonov; method of ranking by "Expert" journal; method by Analytical Center of Financial Information (ACFI) (Savel'eva, 2015) [7-25].

Table 3. Methods of qualitative assessment in banks' efficiency.

\begin{tabular}{|c|c|}
\hline Methods & Description \\
\hline $\begin{array}{l}\text { 1. Method for } \\
\text { assessment of } \\
\text { qualitative } \\
\text { parameters } \\
\text { system by } \\
\text { T.A. } \\
\text { Ponomareva } \\
\text { and, M.S. } \\
\text { Supryagina }\end{array}$ & $\begin{array}{l}\text { 1. Spatial indicators or "environmental quality". } \\
\text { 2. Information indicators describing the information security of customers or } \\
\text { "quality of information support". } \\
\text { 3. Professional indicators characterizing the level of service offered to customers } \\
\text { or "staff qualification" } \\
\text { 4. Claims indicators describing system of data acquisition and processing concern } \\
\text { of customers' reviews and claims (Ponomareva, Supryagina, 2005) }\end{array}$ \\
\hline $\begin{array}{l}\text { 2. Method for } \\
\text { assessment of } \\
\text { services from } \\
\text { marketing } \\
\text { point by N.N. } \\
\text { Pavlova }\end{array}$ & $\begin{array}{l}\text { 1. Criteria of customer requirements to service. } \\
\text { 2. Assessment of expected competitive services. } \\
\text { 3. Evaluation of competitiveness of bank's marketing activities. } \\
\text { 4. Conclusion about the real competitiveness of services (Pavlova, 2004) }\end{array}$ \\
\hline $\begin{array}{l}\text { 3. Model of } \\
\text { banks' } \\
\text { interaction } \\
\text { with } \\
\text { customers by } \\
\text { V.S. } \\
\text { Vikulov }\end{array}$ & $\begin{array}{l}\text { 1. Division of bank's client data base into categories: entities and entrepreneurs; } \\
\text { individuals. } \\
\text { 2. Build three models of customer service: personalized service, management of } \\
\text { targeted companies, responsive model. } \\
\text { 3. Match the category and model (Vikulov, 2003) }\end{array}$ \\
\hline $\begin{array}{l}\text { 4. Method of } \\
\text { expert } \\
\text { assessment of } \\
\text { commercial } \\
\text { bank's } \\
\text { stability by } \\
\text { A.G. } \\
\text { Zahar'yan }\end{array}$ & $\begin{array}{l}\text { 1. Formation of the expert group. } \\
\text { 2. Conduct an expert survey. } \\
\text { 3. Questionnaires processing } \\
\text { Calculation of the coefficient of concordance performed using the following } \\
\text { formula: } \\
W=\frac{12}{m^{2}\left(n^{2}-n\right)} * S=\sum_{J=1}^{n}\left(\sum_{J=1}^{n} R_{i j}-\frac{m(n+1)}{2}\right) \\
m-\text { quantity of experts, } n-\text { quantity of parameters, Rij - weight of } j^{\text {th }} \\
\text { parameter given by } i^{\text {th }} \text { expert. } \\
\text { Summarized results for group of indicators, that characterizing components of } \\
\text { comprehensive sustainability, is an average value: } \\
\qquad V=\frac{\sum s c o r e_{i} * \text { weight }}{\sum} \\
\text { Where } \text { score }_{i} \text { is the score of parameter from } 1 \text { to } 3 \text {; weight } t_{i} \text { is weight score in } \\
\text { significance scale (average of expert scoring) (Zahar'yan, 2004) }\end{array}$ \\
\hline
\end{tabular}




\begin{tabular}{|c|c|}
\hline $\begin{array}{l}\text { 5. Method by } \\
\text { rating agency } \\
\text { "Expert RA" }\end{array}$ & $\begin{array}{l}\text { 1. Indicators of capital. } \\
\text { 2. The quality of assets. } \\
\text { 3. The effectiveness of management. } \\
\text { 4. Profitability. } \\
\text { 5. Liquidity (Karminsky, Myakon'kih, Peresetsky, 2009) }\end{array}$ \\
\hline $\begin{array}{l}\text { 6. Method by } \\
\text { V.S. } \\
\text { Kormonov }\end{array}$ & 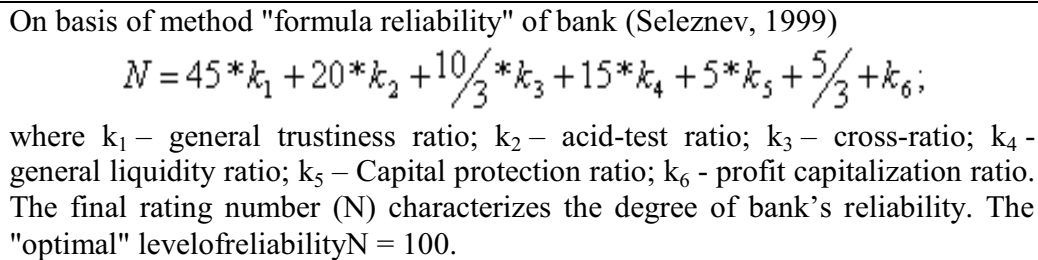 \\
\hline $\begin{array}{l}\text { 7. Method of } \\
\text { ranking by } \\
\text { "Expert" } \\
\text { journal }\end{array}$ & $\begin{array}{l}\text { It consists of two main parts (Seleznev, 1999): } \\
\text { 1. Analysis of banks in the coordinates "profitability-reliability"; } \\
\text { 2. Analysis of dynamic changes. }\end{array}$ \\
\hline $\begin{array}{l}\text { 8. Method by } \\
\text { Analytical } \\
\text { Center of } \\
\text { Financial } \\
\text { Information } \\
\text { (ACFI) }\end{array}$ & $\begin{array}{l}\text { 1. Sufficiency of own capital and reserves; } \\
\text { 2. Quality and real value of total assets of bank; } \\
\text { 3. Quality control and wise management; } \\
\text { 4. Efficiency of inflow and quality of income; } \\
\text { 5. Reasonableness and practice of asset and liability management (Karminsky, } \\
\text { Myakon'kih, Peresetsky, 2009) }\end{array}$ \\
\hline $\begin{array}{l}\text { 9. Method for } \\
\text { determining } \\
\text { the efficiency } \\
\text { Of price and } \\
\text { non-price } \\
\text { competition } \\
\text { by Authors }\end{array}$ & $\begin{array}{l}\text { 1. Determination of basic parameters that influence price and non-price } \\
\text { competition in banking market; } \\
\text { 2. Scoring of the main parameters of price and non-price competition; } \\
\text { 3. Determination of factor loadings on the basis of factor analysis procedures; } \\
\text { 4. Determination of the optimal number of factors; } \\
\text { 5. Defining parameters of price and non-price competition that most correlated } \\
\text { with main factors; } \\
\text { 6. Calculation of factor values; } \\
\text { 7. Calculation of total index value of factors for different periods; } \\
\text { 8. Calculation of augmentation in effectiveness score; } \\
\text { 9. Graphical presentation of the results; } \\
\text { 10. Interpretation of the results. }\end{array}$ \\
\hline
\end{tabular}

In Russian and world practice there are various methods of evaluating the effectiveness of bank's activities. However, a unified measurement system does not exist. Banks use many different methods to assess the effectiveness of its activities. Evaluating the effectiveness of the bank's activities on the basis of quantitative methods involves the calculation of the efficiency in terms of value. Qualitative methods of evaluation require efficiency score. Effectiveness score is presented in calculated and cost values.

\section{Discussion}

Banking competition is one of market competition forms appearing in competition between credit institutions in order to satisfy consumers demand in the process of banking services.

The problem of competition, its appearance in a different market models researched in the works of classic and neoclassic economic schools, such as: A. Smith, D. Ricardo, J. Schumpeter, E. Chamberlin, J. Robinson, A. Cournot, F. Edgeworth, J. Keynes, P. Heyne, F. Hayek, A. Marshall, S. Brue, K. McConnell and others. Their followers R. Bertrand, O. Herfindahl, M. Rosenbluth, E. Lind and others developed the theory of competition offering alternative models of its assessment and use of market power. 
There are three approaches to the competition definition. The first one describes competition as contestation of economic entities in the market. The second one is near of classical economic theory kin consider the competition as an element of market mechanism, which balance supply and demand. [2-23] The third approach based on modern theory of market understanding and study competition as the criterion determining type of industry market.

Table 4. Authors' approaches comparison.

\begin{tabular}{|c|c|c|}
\hline$\#$ & Author & Definition \\
\hline \multicolumn{3}{|c|}{$\begin{array}{l}\text { The first approach characterizes the competition as a contestation for the better conditions regarding the } \\
\text { existence, operation and development of firms. The contestation for the relatively better conditions is } \\
\text { permanent because of its limited nature, so everyone cannot get it at once }\end{array}$} \\
\hline 1 & $\begin{array}{l}\text { Ambartsumov A.A., } \\
\text { Strelikov F.F. } \\
\text { (Ambartsumov, Sterlikov, } \\
\text { 1993) } \\
\text { Kirzner I. (Kirzner, 1973) } \\
\text { L. von Mises(Mises, 1999) } \\
\text { Porter M. (Porter, 1990) } \\
\text { Yudanov A.Yu. (Yudanov, } \\
\text { 2001) } \\
\text { Grigor'ev M.N. (Grigor'ev, } \\
\text { 2010) } \\
\text { Azoev G.L. (Azoev, 1996) }\end{array}$ & $\begin{array}{l}\text { Competition is a permanent mechanism of free } \\
\text { contestation, rivalry of companies in order to achieve } \\
\text { the best results of their business activities }\end{array}$ \\
\hline 2 & $\begin{array}{l}\text { KorotkovA., Tret'yakovN. } \\
\text { (Korotkov, Tretyakov, 2007) }\end{array}$ & $\begin{array}{l}\text { Competition is a contestation between market actors } \\
\text { in order to provide better opportunities for their } \\
\text { products to meet a variety of customer needs }\end{array}$ \\
\hline 3 & Rubin Yu.B. (Rubin, 2010) & $\begin{array}{l}\text { A simple definition of competition can be understood } \\
\text { as conflict contestation for the achievement of better } \\
\text { conditions regarding the existence, operation and } \\
\text { development }\end{array}$ \\
\hline 4 & Nosova N.S. (Nosova, 2009) & $\begin{array}{l}\text { Competition is commonly understood as a set of } \\
\text { market actors' actions, competition between them in } \\
\text { order to achieve advantages over competitors }\end{array}$ \\
\hline 5 & Tot'ev K.Yu. (Tot'ev, 2003) & $\begin{array}{l}\text { Competition is a contestation, a rivalry of individuals, } \\
\text { groups and organizations to achieve better results in a } \\
\text { particular public sphere }\end{array}$ \\
\hline 6 & Lifits I.M. (Lifits, 2009) & $\begin{array}{l}\text { Competition is a form of mutual rivalry between } \\
\text { subjects of market economy }\end{array}$ \\
\hline 7 & $\begin{array}{l}\text { Fathutdinov R.A. } \\
\text { (Fathutdinov, 2000) }\end{array}$ & $\begin{array}{l}\text { Competition is competitiveness, rivalry, intensive } \\
\text { struggle of individuals or entities for the buyer (for his } \\
\text { money), for own survival in conditions of hard } \\
\text { competition law as an objective process of "washing } \\
\text { out" low-quality goods and services in the framework } \\
\text { of anti-monopoly and customer rights legislation }\end{array}$ \\
\hline 8 & $\begin{array}{l}\text { Kiperman G.L. (Kiperman, } \\
\text { 1993) }\end{array}$ & $\begin{array}{l}\text { Competition is the process of interaction, } \\
\text { relationships and struggle of manufacturers and } \\
\text { suppliers during sales; it is economic rivalry between } \\
\text { the distinct producers or suppliers of goods (services) } \\
\text { for the most favorable marketing conditions }\end{array}$ \\
\hline 9 & $\begin{array}{l}\text { The Federal Law of Russian } \\
\text { Federation (The Federal Law } \\
\text { of Russian Federation, 2006) }\end{array}$ & $\begin{array}{l}\text { Competition is a rivalry between economic entities, } \\
\text { whereby their independent actions effectively restrict } \\
\text { ability of each of them to unilaterally influence } \\
\text { general conditions of goods circulation in the relevant }\end{array}$ \\
\hline
\end{tabular}




\begin{tabular}{|c|l|l|}
\hline & & product market \\
\hline 10 & SmithA. (Smith, 1776) & $\begin{array}{l}\text { Competition is fair competition between sellers for } \\
\text { more favorable terms of their products sale }\end{array}$ \\
\hline 11 & Porter M. (Porter, 1990) & Competition isn't a balance, but constant changes \\
\hline 12 & $\begin{array}{l}\text { Ozhegov S.I. (Ozhegov, } \\
\text { 1987) }\end{array}$ & Competition is a struggle, a fight \\
\hline 13 & $\begin{array}{l}\text { MarshallA. (Marshall, 1920) } \\
\text { Competition is a contest between persons especially } \\
\text { when selling or buying anything }\end{array}$ \\
\hline
\end{tabular}

The second approach considers the competition as an element of market mechanism balancing supply and demand. It is the economic process of interaction, relationships and the struggle between companies in market in order to provide the best market opportunities for their products, to meet different customer needs and obtain maximum profit.

\begin{tabular}{|c|c|c|}
\hline 1 & $\begin{array}{l}\text { AzoevG.L., Zav'yalovP.S., } \\
\text { LozovskyL.Sh., } \\
\text { PorshevA.G., RaizbergB.A. } \\
\text { (Azoev, Zav'yalov, } \\
\text { Lozovsky, Porshev, } \\
\text { Raizberg, 2000) }\end{array}$ & $\begin{array}{l}\text { The economic process of interaction, relationships } \\
\text { and the struggle between companies in market in } \\
\text { order to provide the best market opportunities for } \\
\text { their products to meet the diverse needs of customers }\end{array}$ \\
\hline 2 & $\begin{array}{l}\text { PertsovskyN.I. (Pertsovsky, } \\
\text { 2001) }\end{array}$ & $\begin{array}{l}\text { The economic process of interaction, relationships } \\
\text { and the struggle between companies in the market in } \\
\text { order to provide the best market opportunities for } \\
\text { their products, meet customer needs and achieve the } \\
\text { greatest profits }\end{array}$ \\
\hline 3 & $\begin{array}{l}\text { SpiridonovI.A. (Spiridonov, } \\
\text { 1997) }\end{array}$ & $\begin{array}{l}\text { The economic process of interaction, relationships } \\
\text { and the struggle between companies in market in } \\
\text { order to provide the best market opportunities for } \\
\text { their products, meet different customer needs and } \\
\text { obtain maximum profit }\end{array}$ \\
\hline 4 & Svetun'kovS.G. (Svetun'kov) & $\begin{array}{l}\text { Competition is a contestation between market } \\
\text { economy participants for better conditions of } \\
\text { production, purchase and sale of goods }\end{array}$ \\
\hline 5 & $\begin{array}{l}\text { LyginaN.I., LyapinaI.R. (N.I. } \\
\text { Lygina, 2005) }\end{array}$ & $\begin{array}{l}\text { It is element of market mechanism, the shape of } \\
\text { market actors competition for the most favorable } \\
\text { conditions for capital investments }\end{array}$ \\
\hline 6 & Hayek F. (Hayek, 2000) & $\begin{array}{l}\text { Competition is a strive for the purpose to meet criteria } \\
\text { of access to rare goods }\end{array}$ \\
\hline 7 & $\begin{array}{l}\text { Yudanova A.Yu., Murashkin } \\
\text { N.V., } \\
\text { Murashkin A.N., Tyukina } \\
\text { O.N., Senic N.M., Yallay } \\
\text { V.A. (Yudanova, Murashkin, } \\
\text { Murashkin, Tyukina, Senic, } \\
\text { Yallay, 2000) }\end{array}$ & $\begin{array}{l}\text { Competition is a struggle for a limited amount of } \\
\text { effective consumer demand on the available market } \\
\text { segments }\end{array}$ \\
\hline \multicolumn{3}{|c|}{$\begin{array}{l}\text { The third approach considers analysis of market structure and of conditions that prevail there. } \\
\text { It is the monitoring mechanism in market economy, because it forces manufacturers to } \\
\text { properly meet desire of consumers }\end{array}$} \\
\hline 1 & $\begin{array}{l}\text { McConnell C., Brue S. } \\
\text { (McConnell, Brue, 1992) }\end{array}$ & $\begin{array}{l}\text { Competition is a situation where many units compete, } \\
\text { they are independent and are free to enter and leave } \\
\text { market. }\end{array}$ \\
\hline
\end{tabular}




\begin{tabular}{|c|c|c|}
\hline 2 & $\begin{array}{l}\text { Zav'yalov P.S. (Zav'yalov, } \\
\text { Demidov, 1991) }\end{array}$ & $\begin{array}{l}\text { Competition is a part of market environment; } \\
\text { developed market is inconceivable without } \\
\text { competition. }\end{array}$ \\
\hline 3 & $\begin{array}{l}\text { Romanov A.N. (Romanov, } \\
\text { 1996) }\end{array}$ & $\begin{array}{l}\text { Competition is the cheapest method of economic } \\
\text { control, which has no equal. }\end{array}$ \\
\hline 4 & KirznerI. (Kirzner, 2001) & Competition is a "situation" rather than a process \\
\hline 5 & $\begin{array}{l}\text { SidorovichA.V.(Sidorovich, } \\
\text { 2001) }\end{array}$ & $\begin{array}{l}\text { Competition is a part of market space, where } \\
\text { producers appear as acting independently competitive } \\
\text { sellers of goods and services }\end{array}$ \\
\hline
\end{tabular}

As it shown by theoretical studies, we should not completely rely on the comparative characteristics of all market participants and define competitive struggle for all that is best; we should focus on a consumer, on the cost of consumer banking services.

\section{Conclusions}

The concept of "competition" as a fundamental category in marketing, and so widely used in nowadays environment, draws closer and systematic attention of economists and interpreted them differently. Banking competition can be defined as one of the varieties of market competition, which appears in contestation and interaction between credit institutions in order to meet the diverse requirements of consumers in the process of creation and implementation of banking products, thus ensuring the most stable position in the market.

Banking institutions need to constantly evaluate the effectiveness of its activities, as it affects credibility of clients and partners. Price competition is characterized by the fact that only pricing methods used for dealing with competitors. Non-price competition related primarily to changes in quality of services that the most important.

In this case the main purpose of quality control is customer satisfaction, not just release of service with no defects. As the banking market saturation, competition moves from sphere of high technologies in service sector, where the most important parameters are the anticipation of customer expectations and continuous improvement of quality of banking products and services.

The proposed method helps to identify the main variables that determine price and nonprice competition effect in banking market; to set the value (weighting factors), calculated according to specifics of target market; to determine the main approaches for management system of price and non-price competition in target market; to identify the closest competitors and to establish the relative position of bank among other market participants in terms of perception of price and non-price competition factors; to use received information for competitors dossier.

\section{References}

1. A. Ambartsumov, A. Sterlikov, 1000 market economy termins (Cron-press, Moscow, 1993)

2. G.L. Azoev, Competitiveness: analysis, strategy and practice (Center of Economics and Marketing, Moscow, 1996).

3. R.A. Fathutdinov, Strategic marketing (CJSC, Moscow, 2000)

4. V.F. Bogachev, The World of Economics and law 1,7-15 (2012) 
5. N.P. Veretennikov, R.G. Leont'ev,Regional'nye korporacii v sfere telekommunikacij: organizacionnyj aspekt (Vladivostok, 1999)

6. A. Hayek, A. Friedrich. Individualism and Economic Order (Isograph, Moscow, 2000)

7. G.L.Kiperman, Market economics (Republic, Moscow, 1993)

8. M.Kirzner, M. Israel,Competition and Entrepreneurship (The University of Chicago Press, Chicago,1973)

9. I.M. Lifits, Competitiveness of goods and services (Urait, Moscow,2009)

10. A. Marshall, Principles of Economics (Macmillan, London, 1920)

11. N.I. Lygina, I.R. Lyapina,Marketing of goods and service (Forum, Moscow, 2005)

12. N.S. Nosova, Competitive strategy of company or marketing methods of competitive fight (Dashkov \& Co, Moscow, 2009)

13. N.N. Pavlova, Marketing in Russia and abroad 1, 82-89 (2004)

14. N.I.Pertsovsky, International marketng (High School, Moscow, 2001)

15. S. Ponomareva, Marketing in Russia and abroad 1, 47-58 (2005)

16. M. Porter, The competitive advantage of nations (Harvard Business Review, 1990)

17. A.N. Romanov, Marketing (Banks and burses, Moscow, 1996)

18. N.K. Savel'eva, Finance analytics 6(288), 16-27 (2016)

19. A.V. Sidorovich, Economic theory course (Business \& Service, Moscow, 2001)

20. I.A. Spiridonov, International competitiveness and ways to increase the competitiveness of Russia (Infra-M, Moscow, 1997)

21. A.I. Shlafman Mir jekonomiki i prava 4, 4-13 (2011)

22. A. Mottaeva, MATEC 73, 07020 (2016)

23. A.B. Mottaeva, A. Zheltenkov, I. Stukanova, S. Ryabichenko, S. Zhuk, MATEC 73, 07026 (2016) 